\title{
REDISCUSSING THE MEANINGS OF URBANISM
}

\section{REDISCUTINDO OS SIGNIFICADOS DO URBANISMO}

\author{
Clovis Ultramari ${ }^{1}$ \\ Ariadne dos Santos Daher ${ }^{2}$ \\ Marcio Machado ${ }^{3}$
}

\begin{abstract}
The following article is based upon an earlier version of it, published in the Pós FAUUSP journal in 2009, with the title Significados do Urbanismo, in Portuguese. After over a decade, those positions are now revisited. The present text transcribes parts of that earlier version, adds new references and authors, rediscusses its concepts and incorporates emerging topics and trends not discussed at the time.

This article discusses the different meanings of urbanism by its relation with urban planning and urban design. The similarities and differences between these concepts and the fact that they are often used indistinctly are pointed out. The current article is organized around two hypotheses: the first involves a broader understanding of urbanism, which incorporates urban planning; the second is based on the idea that the conceptual distinction between these two fields may be defined according to how close or how far urbanism is from art and architecture. The closer urbanism is to art and architecture, the more it moves away from urban planning. The ideas presented here are intended to be provocative, and the authors are aware of reactions they may generate. This discussion is based on technical literature as well as on debates with other researchers and students. The article starts with an introduction regarding the difficulties and complexities of an epistemological discussion while later sections pointing out similarities and distinctions between the two main concepts. The conclusion makes the authors position clear but suggests that this issue needs further discussion.
\end{abstract}

Keywords: Urban planning. Urban management. Urban design. Urbanism.

\section{Resumo}

Este artigo tem como referência a sua versão anterior, publicada na revista Pós FAUUSP, de 2009, sob o título Significados do Urbanismo ${ }^{4}$. Passada uma década, o presente texto transcreve partes do

\footnotetext{
${ }^{1}$ Doutor em Meio Ambiente e Desenvolvimento Urbano pela Universidade Federal do Paraná. Professor da Pontifícia Universidade Católica do Paraná e do Programa de Pós-graduação em Meio Ambiente e Desenvolvimento, da Universidade Federal do Paraná, Cutitiba - PR, Brasil. E-mail: ultramari@yahoo.com

${ }^{2}$ Doutoranda em Gestão Urbana da Pontifícia Universidade Católica do Paraná. Sócia da Jaime Lerner Arquitetos Associados, Cutitiba - PR, Brasil. E-mail: ariadne.daher1@gmail.com

3 Doutorando em Gestão Urbana da Pontifícia Universidade Católica do Paraná, Cutitiba - PR, Brasil. E-mail: marciomachado80@gmail.com

${ }^{4}$ https://www.revistas.usp.br/posfau/article/view/43614
} 
anterior, agrega novas referências autorais, rediscute seus conceitos e busca assimilar temas emergentes não discutidos à época.

O texto discute os significados possíveis que se tem para o conceito do termo urbanismo e daqueles que lhe são próximos, chegando mesmo a serem confundidos. Para tanto, aborda também suas relações com o planejamento, a gestão e o desenho urbano. Neste percurso, permeando toda a narrativa, está o conceito de cidade, objeto final dos demais. Assim, este artigo ressalta as similaridades e as diferenças entre esses entendimentos e o fato de serem, muitas vezes, usados indistintamente. Os argumentos são construídos a partir de dois pressupostos: o de uma maior abrangência da atuação do urbanismo, o qual incorporaria o planejamento urbano; e o de uma distinção conceitual dessas duas ciências (ou práticas?) poder ser feita a partir de uma maior ou menor aproximação da arte e da arquitetura. Quanto maior a aproximação, mais próximo da faceta de intervenção física do urbanismo estamos; quanto mais distantes, mais claro fica o conceito de planejamento urbano. $\mathrm{O}$ artigo tem caráter provocativo e está consciente da polêmica que exercícios de conceituação geram, e sua estrutura conta com uma introdução que ressalta a dificuldade de uma abordagem epistemológica ou conceitual e partes onde se estabelecem semelhanças e distinções dos conceitos tratados. Sua conclusão, propositadamente, resguarda-se de posicionamentos definitivos e propõe a continuidade da discussão.

Palavras-chave: Planejamento urbano. Gestão urbana. Desenho urbano. Urbanismo.

\section{The conceptual debate}

This paper brings a reflection about urbanism and urban planning as related scientific fields. The study object is the urban reality and also, the region in which it is inserted. From the early stages it is observed that they have as object the city, another term with well-known conceptual shortcomings. Ultramari $(2019 \text {, p. } 290)^{5}$, for example, already warned:

City is a concept that still lacks clear determination, typical of scientific fields in formation; city is an intrinsically incomplete concept, with distinct insertions in equally distinct scientific fields; city is a multidisciplinary concept aiming to reconcile different priorities and research perspectives, with shifting prerogatives taking precedence ${ }^{6}$.

Despite these difficulties, the conceptualization effort is justified by itself. An effort that has received increasing importance in contemporary social sciences studies (Greene, 2020). This conceptualization is required due to the practical necessity of researchers seeking broader dialogues, attesting its potential as considerably important. As a result, in case the results are not so precise, the conceptualization effort is justified by the argumentative processes themselves.

For this paper, besides the two main concepts discussed, it is essential to add urban design and, in an indirect way, urban management. In our discussion, similarities and differences are searched among these concepts, as well as an answer to how they are understood, and how they approach the urban phenomenon. Undeniably structured as an epistemological essay, this article recognizes the conceptual and operational path of urbanism and urban planning, sometimes used interchangeably.

In the last decade, since the first version of this work was published, some significative changes have occurred. Many of these changes were already noticed while others appeared in a more unexpected way. The daily globalization experience undermines the concept of urban as it is blurred with the one of society. Paradoxically, while the idea of a world with no need of the adjective "urban", as it is intrinsic to it, the idea of a complex network of cities, made of independent but connected

\footnotetext{
${ }^{5}$ All quotes were translated by the article's authors when not in English. Originals were included for reference as footnotes.

${ }^{6}$ Cidade constitui um conceito ainda carente de determinação clara, característico de campos científicos em formação; cidade é um conceito intrinsecamente incompleto, com inserções distintas em campos científicos igualmente distintos; cidade é um conceito multidisciplinar e que busca conciliar distintas prioridades e perspectivas investigativas, com a prerrogativa ora de uma ora outra dessas mesmas prioridades e perspectivas.
} 
parts, gains strength. In the urban studies field, the global city theory articulates these facts inside its theoretical framework, enlarging even more the work and study scale of urban planners.

The aim of this article is only to respond to conceptual concerns that arise among those who plan, manage or research the city. In the daily tasks of such works it is possible to observe little certainty about the meaning of urbanism, urban planning, urban design and urban management. Previous studies are not reproduced here, which, in a historical review, retrieve different periods of urbanism and even urban planning. In the original text, the epistemological discussion was the priority. Such choices remain current and relevant: over these ten years, the foundation crisis in urban studies became clearer. Supporting this theoretical effort seems an extra commitment to the urban planner duties, surrounded by "urgent and concrete" tasks:

a discipline that does not recognize the constitution of its fields and approaches can have difficulties to recognize its limits and develop in relation to the; it can have difficulties in an empirical world in constant movement (NETTO et al., 2017, p. $\mathrm{s} / \mathrm{n})^{7}$.

Completing the support of the theoretical thinking, now in another social and economic setting, Brenner (2018, p. 3) also observes the need to develop further more productive ways in epistemological discussions about cities:

it is not obvious how to engage in meaningful intellectual dialogue with critics who are inclined to present our core arguments in such polemical, simplified, or superficial ways. In some cases, denunciatory references to our writings appear to serve mainly as a rhetorical foil.

Even the most basic epistemological parts of a field, such as its very core concepts, have to be rebuilt. According to Brenner and Schmidt (2014, p. 21):

A new vocabulary of urbanization is needed. Inherited analytical vocabularies [...] do not adequately capture the changing nature of urbanization processes, and their intensely variegated expressions, across the contemporary world.

The elaboration of this paper started with the certainty that urbanism, whether as a science, area of knowledge, or even as a technique, would be strongly linked to the idea of physical intervention in the space of cities, changing them or building them with projects and works of beautification, water and sewage, mobility systems, public and private spaces. Although, we also recognize there are other understandings about urbanism which bring it closer to urban planning, especially when its main concern is to organize the way society itself builds and experiences the city.

the concept of urbanism that is a systematic construction of efforts, thoughts, policies, and actions for establishing, developing, maintaining, and sustaining human settlement as a home for everybody who works, live, and play in its spatiotemporal territory (WIRYOMARTONO, 2020, p. 156).

Leme (1999) contributes to clarify this question summarizing the historical path of urbanism in Brazil: first, a dominance of pioneers, followed by engineers-architects, architects and, finally, multidisciplinary teams. This same synthesis is reinforced in the identification, by the author, of the Brazilian urbanism periods: 19th century to the 1960s, what was called "improvements"; from the 1970s onwards, the prevalence of Masterplans of Integrated Development.

\footnotetext{
7 [u]ma disciplina que não reconhece a constituição de seus campos e abordagens pode ter dificuldades em conhecer seus limites e avançar em relação a eles; pode ter dificuldades frente a um mundo empírico em constante movimento (NETTO et al., 2017, p. s/n).
} 
The changing of understandings experienced from the production of the first version of this article is a result, probably, of recalling, for instance, that urbanism, when it wanted to be modernist, did not present itself only as a project of physical intervention in a specific city. On the contrary, as we know, the movement called modernist urbanism was characterized as a corollary, a manual, on how to proceed to reach the ideal city. As a result, urbanism as a "utopia" believed it could alter the city not only as a built space but also alter the society that builds, uses and experiences it.

In fact, this urbanism - and this is the word used instead of urban planning - , not only designs the desired city, but also determines how it should be achieved and lived, that means, believing in the utopia of being able to shape the society living there. However, when considering the antagonism between believing in societal changes based on the design of the proposed urban settlement and thinking about these changes through new relationships between its social components, the article once again differentiates the concepts dealt with here as in its beginning. The insertion, therefore, of issues related to society's relations with the proposed design for the city, once again brings the concept of urbanism closer to that of urban planning.

According to Dias (2020), there was a period in the past in which urbanism was searching to overcome social problems with new urban forms or land use regulations. For this author, the persistence of these problems when cities such as Brasília were created, alert to the limitation of urbanism on fighting social exclusion, thus giving strength to the attributes of the urban planning: a practice proposing to consider different understandings, reconcile interests and submit governmental priorities to the comprehension of the majority.

There is a difficulty in distinguishing the terms and concepts discussed here. Are these terms: urbanism, urban planning and, from a proximity relationship, urban design, a historical evolution of the same idea or differences that coexist temporally? Are they contradictory or complementary? Are they dealing with the same object?

In order to start the debate, it is important to differentiate the action of doing from the previous action of planning. Initially, there is urban planning as the action of planning in which the desired city is presented in a plan, not necessarily in graphic work, such as a Municipal Masterplan. In a second moment, urbanism, the action of physically changing, building, increasing, recycling, or revitalizing, from a clearly intentional design. Concomitantly, there is urban management or municipal administration, responsible for deciding the moment to plan or act; to make urban planning or urbanism.

Urban planning would then be linked to a more traditional understanding of the city: in which it plans it, and envision its future, defines its priorities, in what places to build and not to build, which works to carry out. Once this planning has been finished, it goes to management the role of executing and supervising it. In other words, urbanism would then be linked to architectural and engineering techniques to implement what is physical (the construction works) as previously determined by the planning (the plan). Such simplification should not, however, justify the ending of this discussion about the best way to use these concepts. This linear differentiation must be substituted by the doubt.

The city as an object and the urban as a phenomenon was a conceptual differentiation proposed by Henri Lefebvre already in the 1960s and widespread since then. If in such way understood, city and urban, would be, in turn, the focus of urbanism and urban planning. A society urbanized in all possible places and also in the complex social relationships demands from urban planning its thorough reexamination, for it globally enlarges its field of play. Scott and Storper (2015, p. $\mathrm{s} / \mathrm{n}$ ) subscribe to the existence of a miscegenation of the concepts of city and urban, considering that the term urban "is an incoherent concept, that urban society is nothing less than modern society as a whole, that the urban scale can no longer be separated from the global scale". Revising of the differentiation between urban and city contributes to a possible epistemological update between urban planning and urbanism.

\section{Urbanism and its metamorphosis to urban planning}

If on one hand the so-called utopian proposals, such as those of Fourier's Phalanstères, of Ebenezer Howard's Garden City, and of Tony Garnier's Industrial City Theory, among others, from the turn of the 19th to the 20th century, failed, on the other they generated a wealth of knowledge of the urban problems perceived by then. For Françoise Choay (1965), such proposals lacked a better understanding of the emerging industrial production and of the new social groups' organization.

Within the focus of this paper, the initiatives from this period, although concerned with new problems of a new society, exemplify an urbanism always explained by design, by the shape of the 
desired city. The Urbanisme, as named by Choay, could be confused with urban planning, or even Aménagement $d u$ Territoire ${ }^{8}$. However, in these examples, the graphic proposal, the intention to build and change the built environment is evident.

At the moment, in the genesis of urbanism, the city was still seen as an object of occasional and marginal interest in other sciences, drawing attention from its quantitative aspects - its demographic changes and reasons for its growth - for an urban sociology that was beginning to consolidate. Likewise, the city showed itself as a study object for sciences more concerned with hygienist and sanitary aspects, much in response to a blatant problem that resulted from an accelerated urbanization, poorly planned and with very low quality of life standards.

From that moment on, the city is clearly the central locus of economic relations, flows, interests, wealth and poverty; to enrich, serve and work, gradually abolishing a simplistic relationship of opposition between built and natural or rural environments. Such a scenario, more specifically that of working class housing in London, suggests to Marxist theory an evidently comprehensive understanding, addressing issues about the economy, society, and the impacts of capital's interests on the use of urban land. From that point onwards, which evidences a new process of densification of human settlements, the predominance of the urban phenomenon over any other territorial socioeconomic manifestation is growing.

The consolidation of this process would justify the perspective of total urbanization adopted by Lefebvre, which does not mean a city (concrete object) of global extension, but a global urban phenomenon.

The science of urbanism, suggested by a new phenomenon - the city -, is thus formally configured from a problem: that of a space with facts and transformations perceived as negative, hitherto unknown and happening at an equally unprecedented pace. From this unparalleled scenario, the act of thinking about the city inherits a scientific pessimism that seeks not to repair, but to escape, as it was the case demonstrated by utopian urban planners: fleeing the city, building new spaces, seemed to be the first concrete action of a newborn science. Pessimism, utopia and optimism have been interchanged ever since, with the city sometimes able of being solved, sometimes becoming the problem of world society, sometimes constituting the most adequate space for the development of history.

As for optimism, it seems right to say that it can be provoked or increased by specific actions capable of suggesting that positive transformations in the city are "under way". Urban optimism observed in recent decades in developed and emerging countries would be, therefore, all materialized by renaissance works in central places, iconic architectures and "star architects". The durability and intention of such oeuvres, without question, open a great dialogue of criticism and rejection (see Volner, 2021). Undoubtedly, these scenarios of optimism are strongly opposed to those of the cities from the 1960s until the middle 1980s. Pessimism as revealed by the almost pastoral vision in the urban proposals of Frank Lloyd Wright (1932-1959) or in the disenchantment of Lewis Mumford (1895 - 1990), for example, can summarize these years, in which cities grew at high demographic rates, a generalized economic crisis required new urban management formulas and traditional downtown areas (symbols of a local history and aggregators of a community) experienced degradation .

Fueled by pessimism or optimism of an age, the foundations of urbanism began to consolidate: not only those that justified a physical intervention according to the architect's or engineer's conception, but also according to enlarged understanding: those able to translate the complex synthesis - if that is even possible - of the diverse features of society, in a determined time and space.

Even with a few recurrences (such as the ecological, self-sustaining or environmentally correct cities of the 1980s and 1990s), such complexity of urban factors correlated at different scales signaled the failure of countless attempts - concrete or theoretical - to formulate an ideal city. How to identify this ideal, who it serves and at what moment it could be visualized would therefore be questions not explicitly formulated.

It becomes, therefore, evident that urbanism presents itself as a science focused on a phenomenon that becomes complex both in essence and in the required understanding. Moreover: the scope of such phenomenon is not restricted, and, therefore, cannot be dealt with in this way,

\footnotetext{
${ }^{8}$ If translated as "Organization of the Territory", it would be closer to the concept of urban and regional planning. Focused on the economic development and inequalities between spaces, the Aménagement $d u$ Territoire, like urban and regional planning, is primarily based on regulations and plans, as opposed to the design of physical interventions.
} 
when it takes place in built agglomerations (the cities). Urbanism, or a science of the urban, advances from a marginal position in other sciences, such as sociology, and even from a limited understanding of its object to, procedurally, constitute a science on its own merits; finally independent and aggregating different areas of expertise. In this expansion of its scope, the concept used until then for urbanism, in its narrowest sense, no longer seems to be sufficient. The ambition is for something larger, something that plans not only a focal, concrete action, but that encompasses a broader approach, one of totality, as intended in urban and regional planning.

At the end of this item, it is worth remembering that the ideas presented above are still hypotheses to be better debated with other authors. In any case, in daring to defend this hypothesis, the provocative nature of this article is reiterated.

\section{Urbanism, art and architecture}

It is recurrent, in the epistemological debates of urbanism, to announce its official emergence, as remembered by Françoise Choay (1965), in Ildefonso Ildefonso Cerdá, in his General Theory of Urbanization, from 1867. Cerdá, the person responsible for Barcelona's expansion project in the mid-19th century, used the term "urbe" as a synonym for human settlement and "urbanization" as the process of acting upon the urbe. From these terms derives_"urbanism". In his studies, Cerdá discussed topics ranging from infrastructure to more territorial issues and the system of cities. From his work the concept of urbanism emerges as an expanded understanding of the city supported by "quantitative methods such as means to explain the social interests [...], thus afflicting itself on the utopian line" (ALARCÓN, 2008, p. y/n) ${ }^{9}$.

Hence, with Cerdá, urbanism would surface as a science capable of elaborating criticisms and solutions to the urban space, but always highlighting a concern with the city in terms of creating, correcting, or remaking the built environment. Later, in the 1930s, the French architect Alfred Agache, who also worked in Brazil, would present urbanism as "a science and an art", as a "set of rules applied to the improvement of buildings, street layout, circulation and decongestion of public arteries [...] without neglecting financial solutions" (AGACHE, 1931, apud SANTOS, 2006, p. s/n) ${ }^{10}$.

Limiting the analysis to the works and understandings of Ildefonso Cerdá and Alfred Agache, both concerned with defining the science of urbanism, it can be argued that their professional endeavors could also be characterized as "urban planning" and not specifically as "urbanism". Such assumption rests on the fact that, in the ideas of these authors, representatives of their time, there is a concern with situations that go beyond the simple desire for physical intervention, but which advance towards a more comprehensive understanding of the city or, better said, of the urban life. Specifically, Cerdá, when outlining the layout of Barcelona's expansion, emphasizes community coexistence. And Agache, when defining, in some of his works, a tight functional specialization, was preparing these cities for the future in a procedural way.

On one hand, such approach brought their professional achievements closer to planning, that is, the organization of a forthcoming city. In both cases, the rules were dictated, the development of the city was planned, so that, over time, it would acquire the desired cityscape. On the other hand, the solutions proposed by these urbanists were still far from provisions of a more structural nature, which would consider the complexities of social and economic forces that truly shape cities. However, in a more expedite evaluation of the work of Cerdá or Agache, they seem to believe in the construction of a new city by the powers of the design of the urban space, through the design of the manifestation of the desired phenomenon, and not through the mediation of urban dynamics (social, political, economic and cultural clashes at different scales).

This distinction also reminds us of the erroneous separation of planning and acting, making planning and urbanism present themselves not only as distinct, but also as opposites. Sarah Fedlman (2005) illustrates this "discord" through the opposition of Professor Anhaia Mello, creator of the São Paulo Regional Plan, to the work of the mayor of São Paulo, Prestes Maia, recognized for his

\footnotetext{
9 “cuantitativos como medios para explicar los hechos sociales [...], alejándose de esta manera de la línea de los utópicos (ALARCÓN, 2008, p. s/n).

10 "uma ciência e uma arte", como um "conjunto de regras aplicadas ao melhoramento das edificações, do arruamento, da circulação e do descongestionamento das artérias públicas [...] sem descurar as soluções financeiras” (AGACHE, 1931, apud SANTOS, 2006, p. s/n).
} 
Haussman-inspired Avenues Plan. The first called for the "enabling of the urbanism sector" to create plans, and not just road planning operations. The second, by criticizing these same plans:

We do not believe that municipal urbanism has stopped making 'plans' due to incapacity or misguidance, but quite simply because this field is vague and their technicians would be deprived of an accredited and democratically invoked opinion base... Would they be working in the air and wasting time, which in fact they have made good use of, doing precisely road projects... (PRESTES MAIA, 1954, apud FELDMAN, 2005, p. $\mathrm{s} / \mathrm{n})^{11}$

Still referring to Feldman (2005), the mastery of architects and engineers in urbanism can be observed in Mello's words when supporting the specialized training of urbanists, that is, not as appropriation of other professional expertise. The professor emphasizes the role of the architect as "expert in the work of building well" and the civil engineer as "expert in the construction of streets, bridges, paving, transport". Extrapolating the concept, and adding a multidisciplinary profile to urbanism, he also considered "necessary and essential the collaboration and cooperation of the jurist, the legislator, the economist, the sociologist..." (ANHAIA MELLO, 1928, apud FELDMAN, 2005, p. y/n $)^{12}$.

Returning to Agache's arguments, we see that he defines urbanism in a time before his own professional works as such, in the actualization of urban occupation plans, which he developed more intensely in the 1940s. This decalage might explain the conceptual incongruity in respect of "his" science. In reality, Agache, in his definition of urbanism, reproduces the concern with form and aesthetics, that is, with architectural representation. With no doubt, if seen by its genesis, urbanism will always be associated with architecture and art; always as a science that observes its object through the bias of this double spectacles.

However, despite this early connection - which would certainly influence the future of urbanism - there is a seesaw process that combines proximity and distance in its relationship with architecture and art. The other hypothesis presented in this article is that, by distancing urbanism from art and architecture, we bring the activity of "desiring to change the city" closer to urban planning, which is more concerned with the intricate system of socioeconomic relations.

Following this temporal trajectory from the 1980s, in Brazil, one can speak of an almost rupture between urbanism and architecture, with urbanism aiming at structural solutions for cities by waiting for major societal changes to solve urban problems. To illustrate this distancing of urbanism from its more pragmatic roots, it is worth remembering Gutman (1981), who feared the increase in the number of professionals who qualified as urbanists that would abandon the concern with the transformation and control of the physical environment to take care of social and cultural modelling of the city.

Likewise, Manuel Castells, a decisive reference to understand the city in the 1970s and 1980s, summarizes the "urban question" as a phenomenon that necessarily goes beyond "the deformation of reality by positivism" (1983; first edition 1971 , p. y/n). With these words the author rejects the idea of trying to understand the urban phenomenon in a positivist or even technicist way, which ignore more complex forms of a social, economic, and political realities.

Already in the late 1980 s, in contrast to the previous decade, by virtue of urban renaissance initiatives in cities in Europe and in the United States, there was an unprecedented alignment between urbanism and architecture. Combining a discourse of requalification of central areas of cities, urbanism would, once again, seek an approximation with architecture and the arts. With the first, such proximity occurs in the implementation of the so-called "great urban projects", almost always with architectural icons designed by renowned professionals which would, supposedly, ensure competitiveness in the global arena to the city that contains them. With art, urbanism comes

\footnotetext{
${ }^{11}$ Não cremos que o urbanismo municipal tenha deixado de fazer 'planos' por incapacidade, ou má orientação, mas muito simplesmente porque este campo é vago e neles os técnicos estariam desprovidos de base opinativa credenciada e democraticamente invocada ... Estariam eles laborando no ar e perdendo tempo, que aliás têm aproveitado bem, fazendo justamente projetos viários... (PRESTES MAIA, 1954, apud FELDMAN, 2005, p. s/n).

12 "necessária e imprescindível a colaboração e cooperação do jurista, do legislador, do economista, do sociólogo..." (ANHAIA MELLO, 1928, apud FELDMAN, 2005, p. s/n).
} 
closer not only through visual expressions materialized in the same large-scale projects, but also in the function of these buildings, housing and fostering artistic, cultural and entertainment activities.

\section{Changes and permanencies}

Despite widening the understanding of its own object, urbanism still retains many of its original traits, which is actually one of the main causes of criticism to its outcomes. Two concerns arise from this. The first is the reach of the architect's drawing board's desire - albeit translated into concrete intervention - on society's relations. The second is about the risk that, by broadening the bases of its understanding, adding socioeconomic concerns to its proposals, urbanism may believe it can change society. If focused on the physical transformation of space, how to explain the use of the concept of urbanism - and not urban planning - to translate the interests, for example, of the modern movement? Without necessarily criticizing, Françoise Choay (1965) states that urbanism, as claimed by Le Corbusier, is understood as a scientific universality capable of synthesizing the correct point of view on the problem of cities.

In fact, it is from the modernist urbanism, a period triggered by the International Congresses on Modern Architecture / CIAMs, and of which Le Corbusier is one of the most prominent spokespersons, that the understanding of urbanism as an extension of the professional activity of the architect becomes more acute and, thus, opposes itself to an increasingly demanded multidisciplinary understanding. A field still reserved majorly to architects, urbanism faces the risk of being implemented through concrete measures capable of transforming the physical base of a given urban space, or a part of it, but of lacking a more comprehensive political and social vision. Thus, if its work is reserved for specific specialists, as stated by Choay (op. cit.), urbanism is ambiguous. Therefore, in urbanism, the belief in solving the urban problems through its technique and its intention to propose an ideal city model, based on hegemonic canons for each of the times it experiences, persists.

It is in the 1950s, during the post-war reconstruction period, in Europe and in the United States, says Choay (op. cit.), that urbanism undergoes, once again, major changes. Now it receives contributions from different perspectives, guaranteeing a necessarily more analytical and even critical view of the city as a space for the relationship of different social classes. This time, urbanism would definitely no longer be a solitary field of action for the architect, categorically rejecting statements such as Le Corbusier's, almost of a corporatist nature:

... the "urbanist" is nothing more than the architect. The first organizes architectural spaces, fixes the place and destination of the constructed continents, links all things in time and space through a network of circulations. And the other, the architect, although interested in a simple dwelling and, in this dwelling in a mere kitchen, also builds continents, creates spaces, decides on circulations. In terms of the creative act, the architect and the "urbanist" are one (LE CORBUSIER, 1985, apud SOUZA, 2002, p. s/n) ${ }^{13}$.

We conclude, therefore, on the so-called ambiguity of urbanism, its genesis that values physical intervention, the permanence of this priority in its practice, and its recurring mutation, at one time proposing to build a new city from a new society, and at another redefining society based on its interventions. Thus, even keeping the particularities of their emergence, always linked to their original sciences, architecture and art both approach and distance themselves from what seems to be the multidisciplinary concern of urban planning.

The alleged exclusivity of urbanism to architectural professionals, considering all the impact this generates on the development of this science, makes the distinction between urbanism and urban planning explicit.

\footnotetext{
13 ... o urbanista nada mais é que o arquiteto. O primeiro organiza os espaços arquitetônicos, fixa o lugar e a destinação dos continentes construídos, liga todas as coisas no tempo e no espaço por meio de uma rede de circulações. E o outro, o arquiteto, ainda que interessado numa simples habitação e, nesta habitação numa mera cozinha, também constrói continentes, cria espaços, decide sobre circulações. No plano do ato criativo são um só o arquiteto e o urbanista (LE CORBUSIER, 1985, apud SOUZA, 2002, p. s/n).
} 
If urbanism and urban planning are concerned with the phenomena shaping the city, expanding it, evidently, to regional and macro-regional spaces, they differ more clearly in the way they act. While urbanism remains less multidisciplinary and historically concerned with the form that the city can take, due to the deceptively homogeneous land use and occupation of the urban agents, urban planning is concerned with the conflicts that this use and this occupation necessarily generate over space of the city. Needless to say, while the first survives in its objectives and responsibilities in a more monodisciplinary way, the second, necessarily, seeks the difficult articulation of countless other sciences. The difference between one and the other does not mean that urbanism can exist without planning; without considering a previous moment in which to plan and a moment in which the planned is executed. In fact, it does not seem plausible to envision an urban work, an intervention project, without first planning it; by the same token, one does not plan something that one does not believe can actually happen.

If the origin of urbanism could be dated to the mid-nineteenth century, urban planning, in turn, seems to emerge as a more explicit desire for state regulation in the post-1945 period and with greater vigor in socialist and communist countries, precisely where the importance of the state intervention in society and the economy would be greater. However, in the discussion about the differences between one and the other, it is worth remembering that cities were built, destroyed and updated from periods as remote as the phenomenon of urbanization itself. Likewise, thinking prior to acting, although not formulated with scientific clarity, is evidently found in past times as well. This finding, therefore, puts in doubt the separation between one science and another and its emergence at a specific moment in history. This allows, perhaps, the indistinct use of these two terms and, most importantly, implies the impossibility of summarizing them conceptually with clarity. In addition to the difference between the times of emergence of one and the other, believing that different situations created different demands, it is important to emphasize the distinction of each one in facing the urban phenomenon.

Another way of looking at the difference between urbanism and urban planning is to consider the latter as an expanded concept, a broader science. Planning would therefore occupy itself with activities related to research, various sectoral plans, regulation and control of land use and related activities, such as guaranteeing services (education, health and safety) and basic infrastructure (water, sewage networks, paving, transport).

From such a wide scope of action, urban planning would coexist with other sciences, even mingling itself, at times, with sociology, geography, economics and political science. Thus, the idea of urban planning being presented as an area of knowledge with an eminently multidisciplinary character and concerned with the societal way developed in its space of interest, the city, is confirmed. At the other extreme, urbanism would be concerned with parts of a city or, as it is always remembered, with the proposition of new cities, in a utopian posture when seeing a reformulated society emerge from a glittering design of the space to be occupied.

To exemplify, albeit partially, these ideas, the so-called New Urbanism is taken, always understood as an "urban design movement" as in international literature; which demonstrates the primary concern with the built environment, with architecture and infrastructure. The principles of this movement, limited to parts of a city, constitute a specific design for a specific urban occupation of space. Thus, urban design (here understood as urbanism) is distinguished from urban planning also as in international literature (closer to the Brazilian definition of urban planning, for example).

\section{The power of desire}

Viewed from a rationalist and positivist perspective, the city is a system that can be ordered, corrected and maintained in the way it was idealized. Based on this premise given to urbanism, its professionals propose to formulate projects (ideas represented graphically and not just in words) that synthesize a desire for an ideal city. Let's make a project, let's respect that project and, thus, the ideal city will come true: this seems to be, therefore, the rationalist maxim granted to the urbanist professional. The architect, used to another maxim, that it is possible to play God, arrogantly and easily accepts such risky endeavor.

Based, therefore, on ideas capable of being transformed into concrete interventions, urbanism would be subject to criticism for proposing, in a simplistic way, to correct the wrong and avoid the evil. Constituting what Françoise Choay (1965) would call progressive urbanism and 
always defended by Le Corbusier, in the idea of a universalism of modernist urbanism. It would be criticized for its presumption in altering social, economic and cultural aspects.

Despite the criticisms and even the almost hegemonic distrust on part of the academy in relation to modernist urbanism, the practice of seeking a functional city, the ideal city model, physical intervention as the main transformative source of the city endures among us to this day.

If the concept of urbanism has long been confirmed as that of a science critical to the society on which it operates (sometimes proposing new cities, sometimes reformulating parts of existing ones), its tools are limited to altering only the concrete. More important than its creator, the urbanist is its created object, the new city; this one indeed capable of changing everything. When the object is created, the task of changing society is delegated to it. The failure of numerous urbanistic attempts, different in the design of the proposed city, but similar in their indifference towards the permanence of old socioeconomic relations, confirms this idea.

On the one hand, urbanism is adopted as an instrument of strategic action and visible results in a short period of time; on the other, urban planning serves those who believe in the structural transformation of society. In the equidistance of these professional attitudes, a fertile field of action is left unattended. However, the current situation of neoliberal option does not contribute to this conjunction. If the role of the State is reduced and the interest of capital is enhanced, urbanism, with its more monodisciplinary profile, is valued because it believes that, pragmatically, it can correct mistakes and build a better and, ideally, more competitive city.

Without being able to quote particular_research on the subject here, empirical knowledge may indicate that, in Brazilian universities, the graduate programs of architecture and urbanism, still influenced by a period of greater relevance of the State, the study of the construction work, infrastructure, transport and even popular housing has been systematically abandoned to prioritize planning in its strictest sense, that is, the law and the desire expressed in words. In Brazil, in the 2000s, again as an example, this fact was exacerbated by the proliferation of municipal masterplans (here in the sense of comprehensive city plans with land use plans associated to them) were sufficient to build an urban policy: the city's problems are discussed, opportunities for democratic debate on "the desired city", but the necessary and long-needed transformations are postponed.

Right or wrong, the teaching of the law and the planning process was valued at the expense of the practice of intervention, whether carried out by private capital or by the State, equally with entrepreneurial capacity. Similarly, for the North American context, Susan S. Fainstein (2005, p. $\mathrm{s} / \mathrm{n}$ ), when detecting this separation between thinking about the city - in this article, an action more linked to the concept of urban planning - and the intervening in this space, an activity linked to the concept of urbanism, concludes by the separation between learning to plan, making diagnoses and intervening:

Programs in city and regional planning typically have one set of courses devoted to the process of planning (planning theory, planning methods), while another group treats the context (structure of cities and regions, urban history) and the object of planning (e. g., redevelopment policy, environmental policy) with little reference to theories of the planning process.

The reduced relationship between studying a phenomenon and intervening upon it suggests a contemporary distancing between urban planning and urbanism.

What was previously sought as an advancement in the understanding of urbanism, valuing its thematic and professional expansion, today seems to show signs of weakness again, but in the opposite direction. Such change in professional attitude, scientific understanding and even ideological positioning, which this article risks superimposing on an eventual transformation of urbanism into urban planning, can be traced in the synthetic statement of Jean Louis Saibib (apud FAINSTEIN, 2005, p. y/n), for those who think the urban question follows the trajectory "from a primarily design profession to social science".

The old and criticized conception of urbanism merely reified today would risk disappearing, thus bringing it, once again, closer to urban planning. Despite strong criticisms against an urbanism of details, small repairs, design, or the magnificent, through large iconic works, paradoxically, we would be deprived of this urbanism and involved, more and more, by architectures, alone (KOOLHASS, 1995 ). This concern is, therefore, part of a larger debate, that of the doubt between 
valuing a piece of work or valuing the city as a whole. The second option seems to be the majority in the scientific literature; however, without exclusivity. Volner (2020, p. s/n), for example, states that

For decades, a cavalcade of scholarly stars - Peggy Deamer, Mike Davis, Fredric Jameson, Manfredo Tafuri, pick your fighter - has turned in thrilling critical performances on Marxist themes, giving us essential and often startling insights into the built environment.

However, Volner proceeds to defend a new critique, of a possible and necessary coexistence between the particular work and the concern with the city in its entirety.

\section{Urban design and urban experience}

Although this article is already moving towards its conclusion - a task that one considers the most difficult -, it is still worth announcing a discussion on another term that has a strong conceptual and professional relationship with architecture, urbanism and also with urban planning: urban design. Therefore, it is necessary to make use of the discussion brought by Vicente del Rio (1990), for whom urban design can be understood as a specific area of action of urbanism. Thus, urban design would be the detailing of a larger intervention project, such as installation projects that complement the architectural project. We would be here, therefore, on the smallest possible scale of urban planning, going beyond the intervention itself, but advancing into detail. Such detailing, in a first analysis, erroneously brings us closer to the beautifying goals previously practiced by urbanism in its genesis in the 19th century. However, it is important to note that urban design today is the result of technique, functionality, technology, of the partaking of the space by different uses and different agents, revealing a concern much more with function than with form.

However, the sequence of urban planning, urbanism and urban design often seems to correspond to a hierarchy of scales. Planning would be the only scale capable of being concerned with the regional context of a city or of the different groups that make up its society; urbanism would have as a scale that materialized by the urbanized space and/or to be urbanized, and urban design concerned with the detail of the intervention.

Aware of the complexity of this theme, this article cannot, however, fail to identify another hierarchy between these three concepts. The urban design is maintained as a projectual detail of the intervention; however, the hierarchy between urbanism and urban planning is blurred. Erminia Maricato (2000: $\mathrm{s} / \mathrm{n}$ ), when alerting to the fact that the subservience of many interventions in the urban space reinforce the interest of a political and economic hegemony, states: “... Brazilian urbanism (understood as urban planning and regulation ) is not committed to the concrete reality, but to an order that concerns only one part of the city..." ${ }^{14}$. The author's concern here is to reiterate the importance of thinking about actions for the whole of a city and not for its parts considered legal. The deepening of this discussion could confirm whether this quote presents a different concept of urbanism from the one presented here, understood as planning and regulation and not necessarily as a proactive intervention in the city's space. Such a quote can also simply confirm the indistinct use of the concepts of urbanism and urban planning.

Advancing the argument raised by Maricato, Brasilmar Ferreira Nunes, in a text by Nunes and Lacerda (2017, p. s/n), it is explicit when considering the possible link between urbanism and market interests, precisely because of its attribute of practice that involving civil society works and real estate evaluation:

If, in its origin, urbanism is consolidated from the need to seek solutions to urban chaos [...], it establishes itself as a discipline that still continues to organize the growth of cities, but it is also one of the most important elements. expressive of the transformation of urban space - and the city - into merchandise $(\mathrm{y} / \mathrm{n})^{15}$.

\footnotetext{
14 “... o urbanismo brasileiro (entendido como planejamento e regulação urbanística) não tem comprometimento com a realidade concreta, mas com uma ordem que diz respeito a uma parte da cidade apenas..."

${ }^{15} \mathrm{Se}$, em sua origem, o urbanismo se consolida a partir da necessidade de procurar soluções ao caos urbano [...], ele se firma como disciplina que continua ainda a organizar o crescimento das cidades, mas se coloca também como um dos elementos mais expressivos da transformação do espaço urbano - e da cidade - em mercadoria (s/n).
} 
Such fear, or criticism, nevertheless, is not revealed without the confidence that this same urbanism can be implemented to build a more suitable environment in which to live.

In addition, Brasilmar is also categorical in the understanding that urbanism is contained by urban planning: "Among the offer of physical infrastructure for collective services [...] contemporary urbanism is consolidated as an aspect of urban planning, particularly the one under direct or indirect responsibility of the State" (op. cit., p. s/n ${ }^{16}$ ).

When Villaça (1999) reviews the history of what he calls urbanism in Brazil, once again the concept seems to be comprehensive, either because of historical determinations or because of the conceptual synthesis adopted. For this author, urbanism from the 19th century to the 1930s of the 20th century is characterized by plans for beautification and amelioration, with hygienic or sanitary purposes; from the 1930s to the 1990s, the Brazilian city was being planned to face different problems, especially those resulting from accelerated growth; from the 1990s onwards, the action would be marked by a post-urban reform period. If, within this timeframe, the aforementioned author does not identify a more structural approach for changing the city, the urbanism of the period analyzed by him corresponds to the concept that is suggested to be adopted in this article.

While this text brings attention to the validity of the conceptual discussion, it recognizes the difficulty that one has, in the field of urban studies, to convince and justify such importance. In recent decades, some attempts to update the terminology used in the practice of urban planners have been consolidated and, with this, progress has been made in defining this field as a specific area of knowledge. Not only concepts acquired more precise contours, but also many terms proliferated. Several of these terms function above all as instruments for the popularization of goods and services; for the promotion of congresses, of individual projects in lectures, books or technologies associated with them. Such pulverization of terms contributes little to coherent vocabulary advancements in terms of epistemological density. Tested and discussed terms and concepts, such as global cities, sustainable cities, resilient cities, smart cities, all on an endless list, become ephemeral.

regardless of the crucial differences among these concepts, cities often embrace several concepts simultaneously when devising social policies, designing municipal services, and initiating thematic projects (HATUKA et. al, 2018, p. 161)

On the one hand, the possibilities of understanding urban space are expanded in an attempt to respond to the epistemological crisis previously announced in this work; on the other hand, some of these terms and their understandings seem to lack further research and more systematic testing of their applicability.

\section{Conclusions}

If, throughout history, the so-called urbanism or urban planning had different ways of implementing and naming themselves, the correct conceptualization of the terms discussed here would only be possible if conceived within a defined historical moment. In this epistemological discussion, concepts change, confusing themselves with those of other sciences, at the same time that the ways of seeking a certain city model change. At some point, especially in modern urbanism, the ideal city was sought through regulations and separation of functions; at another time, the simple regulation of land use was valued; yet at another time, urbanism sought the sustainable city, valuing the study, the protection of the natural environment; finally, it also sought the democratic city, valuing community participation. This same reasoning, which characterizes urbanism as a practice that is updated and which accumulates more and more responsibilities, is reiterated by Bernardo Secchi (2005). For this author, urbanism follows a trajectory of actions that expands: from local concerns with very specific issues of the built environment, according to the demands of a certain group of agents in the city, to a difficult compromise of consensus.

In changing paradigms, the tools, with which urbanism works, have changed, sometimes approaching the intervention or even the modeling of a physical space, sometimes approaching the construction of a future city through, only, a visual explanation of an urban desire in design or in

\footnotetext{
16 "Entre a oferta de infraestrutura física para os serviços coletivos [...] o urbanismo contemporâneo se consolida como vertente do planejamento urbano, justamente aquele sob a responsabilidade direta ou indireta do Estado"
} 
law. In these comings and goings, urbanism and urban planning would at times be closer, but at others would drift apart.

This article sought to recuperate some of the debate about the concepts of urbanism and urban planning. And, at any point, it attempted to risk a new conceptual construction or even to synthesize what had been previously developed by other authors.

At some point, urbanism seemed to result from a larger science - urban planning. In others, it is certain that it would be correct to understand it in reverse. Thus, urban planning would be part of a larger science called urbanism. At other times, it is suggested that urbanism and urban planning can be used without distinction.

It is clear, however, as explained by Secchi (op. cit.), when he tells us about the "end of the author", that with each increase in the professional complexity of urbanism/urban planning, we must address an understanding, which in necessarily multidisciplinary and willing to submit itself to the community agreement, according to socioeconomic and political realities.

We could, exaggeratedly, assume urbanism as a science whose objective is to organize the natural, constructed and societal elements, in the space occupied or to be occupied by a given human settlement. This concept could also be expanded to address this set of elements in relation to its regional space; to the national and international network of cities. In practice, this same urbanism could be understood as a science that uses, primarily, zoning and physical interventions for its implementation as a practice. At one time, the concept is broad and pretentious; at another, the practice is reductionist.

\section{References}

ALARCÓN, María Teresa. El Plan Cerdá para Barcelona y el urbanismo argentino del siglo XIX. Available at: https://studylib.es/doc/5546955/el-plan-cerd\%C3\%A1-para-barcelona-y-el-urbanismoargentino-del Access in: August. 2020.

AGACHE, Alfred. Cidade do Rio de Janeiro, remodelação, extensão e embelezamento (Plano Agache). Rio de Janeiro: Foye Brésilien, 1930.

BRENNER, Neil. Debating planetary urbanization: For an engaged pluralism. Environment and Planning D: Society and Space, vol. 36, no. 3, June 2018, pp. 570-590, https://doi.org/10.1177/0263775818757510 Access in: January 2021.

BRENNER, Neil. SCHMID, Christian. The 'Urban Age' in Question. International Journal of Urban and Regional Research, vol. 38, 2014, pp. 731-755. https://doi.org/10.1111/1468-2427.12115 Access in: January 2021.

CASTELLS, Manuel. A questão urbana. São Paulo: Paz e Terra, 1983.

CHOAY, Françoise. O urbanismo, utopias e realidade, uma antologia. São Paulo, Perspectiva: 1965.

DEL RIO, Vicente. Introdução ao desenho urbano no processo de planejamento. São Paulo: Pini, 1990.

DIAS, Edson dos. Resgatando o movimento modernista urbano: A expressão de uma conjuntura histórica que marcou as cidades do século XX. Revista Geo Notas, Maringá: Departamento de Geografia, Universidade Estadual de Maringá, v. 4, n. 4, 2000. Available at: http://www.geonotas.uem.br/geonotas/ Access in: May 2018.

FAINSTEIN, Susan S. Planning Theory and the City. Journal of Planning Education and Research, vol. 25, no. 2, Dec. 2005, pp. 121-130. https://doi.org/10.1177/0739456X05279275 Access in: May 2021.

FELDMAN, Sarah. Planejamento e zoneamento. São Paulo: 1947-1972. São Paulo: Edusp/Fapesp, 2005. 
GREENE, Catherine. Nomadic Concepts, Variable Choice, and the Social Sciences. Philosophy of the Social Sciences, vol. 50, no. 1, Jan. 2020, pp. 3-22. https://doi.org/10.1177/0048393119878783 Access in: May 2021.

GUTMAN, Robert. La generación de las calles. In: ANDERSON, S. (Ed.). Calles: problemas de estructura y diseño. Barcelona: Gustavo Gili, 1981, p. 259-275.

HATUKA, Tali; ROSEN-ZVI, Issachar; BIRNHACK, Michael; TOCH, Eran \& ZUR, Hadas. The Political Premises of Contemporary Urban Concepts: The Global City, the Sustainable City, the Resilient City, the Creative City, and the Smart City. Planning Theory \& Practice, vol. 19, no. 2, 2018, pp. 160-179. https://doi.org/10.1080/14649357.2018.1455216 Access in: February 2021.

KOOLHAAS, Rem. What ever happened to urbanism? In: KOOLHAAS, Rem; MAU, Bruce. Small, medium, large, extra large. Nova York: Monacelli Press, 1995.

LE CORBUSIER. Os três estabelecimentos humanos. São Paulo: Perspectiva, 1981.

LEME, Maria Cristina da Silva (Org.). Urbanismo no Brasil: 1895-1965. São Paulo: Studio Nobel/ FAUUSP/Fupam, 1999.

MARICATO, Ermínia. As ideias fora do lugar e o lugar fora das idéias. Planejamento urbano no Brasil. In: ARANTES, Otília et al. A cidade do pensamento único. Petrópolis: Vozes, 2000.

MUMFORD, Lewis. A cidade na história: Suas origens, suas transformações, suas perspectivas. São Paulo: Martins Fontes, 1965.

NETTO, Vinicius M.; FISZON, Maria; MOREIRA, Maria Clara, MORAES, Ivo. Pesquisa Urbana no Brasil: uma leitura inicial, Encontro Nacional da Associação de Pós-graduação e Pesquisa em Planejamento Urbano e Regional; São Paulo, 2017. Disponível em http://anpur.org.br/xviienanpur/principal/publicacoes/XVII.ENANPUR_Anais/ST_Sessoes_Temati cas/ST\%2010/ST\%2010.4/ST\%2010.4-03.pdf Access in: May 2021.

NEW URBANISM. Official website. https://www.cnu.org/ Access in: May 2019.

NUNES, Christiane Girard Ferreira; LACERDA, Norma. Planejamento urbano, arquitetura e urbanismo: a serviço de uma outra geografia? Brasilmar Ferreira Nunes (em memória). Revista Sociedade e Estado, v. 31, Número Especial Sociedade e Estado 30 anos - 1986-2016. pp. 989-1001. https://doi.org/10.1590/s0102-69922016.0spe0008 Access in: May 2019.

SANTOS, José Lázaro de Carvalho. Reflexões por um conceito contemporâneo de urbanismo. Malha Urbana: Revista Lusófona de Urbanismo, no. 3, 2006, pp. 2-24. https://recil.grupolusofona.pt/handle/10437/2174 Access: November 2019.

SCOTT, Allen J.; STORPER, Michael. The Nature of Cities: The Scope and Limits of Urban Theory. International Journal of Urban and Regional Research, v. 39, 2015, pp. 1-15. https://doi.org/10.1111/1468-2427.12134 Access: March 2021.

SECCHI, Bernardo. Primeira lição de urbanismo. São Paulo: Perspectiva, 2005.

SOUZA, Marcelo Lopes de. Mudar a cidade: Uma introdução crítica ao planejamento e à gestão urbanos. Rio de Janeiro: Bertrand Brasil, 2002.

ULTRAMARI, Clovis. O fim das utopias urbanas. Studio Nobel: São Paulo, 2005. 
ULTRAMARI, Clovis. Significados do urbanismo. Pós FAUUSP [Internet]. 0(25), 1 de junho de 2009, pp. 166-84. https://www.revistas.usp.br/posfau/article/view/4361 Access in: May 2021.

ULTRAMARI, Clovis. Conceito de cidade: dificuldades e razões para formulá-lo. Revista Brasileira de Gestão e Desenvolvimento Regional, v. 15, n. 6, dez. 2019. Available at: https://www.rbgdr.net/revista/index.php/rbgdr/article/view/5201/859 Access in: May 2021.

VILLAÇA, Flávio. Uma contribuição para a história do planejamento urbano no Brasil. In: DEÁK, Csaba; SCHIFFER, Sueli Ramos (Orgs.). O processo de Urbanização no Brasil. São Paulo: Edusp/ Fupam, 1999.

VOLNER, Ian. A new book about architecture and capitalism reveals the problem with today's mode of criticism. The Architects Newspaper. April 28, 2021. Available at: https://www.archpaper.com/2021/04/icebergs-zombies-and-the-ultra-thin-architecture-andcapitalism-in-the-twenty-first-century/ Access in: May 2021. 